\title{
Roll-on Container
}

National Cancer Institute

\section{Source}

National Cancer Institute. Roll-on Container. NCI Thesaurus. Code C149888.

A container, usually a bottle, fitted with a roll-on applicator 